\title{
A BRILLIANT CAREER: LIFE AS A LAW TEACHER
}

\author{
NEIL GOLD*
}

\section{BACKGROUND}

I had aspired to a career in teaching for a long time. But when I decided to go to law school instead of pursuing graduate studies in French language and literature, I thought I had finally decided against this career choice. I had chosen law because of its stability and reliability as a profession - and it would provide a certain level of income too! Like many other kids growing up I also had my standard court room heroes, but it was neither Raymond Burr's Perry Mason nor EG Marshall's Defender that really stirred my interest in the practice of law. Before entering law school I had worked as a clerk in a law office and had some idea about the more routine aspects of legal practice, especially as they relate to conveyancing and small scale collection litigation. This experience did not inspire me to enter a career in law either. I studied law in the end without much focus other than it might provide me with a stable, reliable and remunerative career. Teaching would provide the former two but not the latter. And besides, the idea of teaching law seemed far beyond my ken. To me, then, a choice to attend law school was a choice against teaching. It never once occurred to me I might teach law one day!

Law school began a late transformation for me. It was a time of slow intellectual awakening when for the first time I faced, albeit obliquely then, the social and economic issues which I of course eventually found were always reflected in legal doctrine. But in fact, my legal education, while providing a pad to launch my 
interest in perplexing, subtle and challenging issues, laid a groundwork for me as a legal educator only through its mostly negative effects on me as an individual. I found the study of law alienating, competitive, lacking in direction, and peopled by teaching staff and students both fundamentally disinterested in the learning-teaching process and the substantial issues of moment which underlie most law study. My classmates were always more interested in jobs at the major law firms or their trading accounts with their brokers than in asking questions about law's meaning or purposes. For a long time in law school I felt like a lost spelunchian trapped in a cave whose entrance had closed and whose exit was obscured by stalagmites and stalactites of indifference and coldness. No one seemed to care about learning, students or the values which were or might be reflected in law'.

Regrettably, although there were many fine people with whom I studied law, the overall feeling I had about my legal education experience was that it was designed to distance me from reality, to separate intellect from emotion, to numb my sensitivity to the hurts and struggles of individuals, and to embolden me in the acceptance of the underlying but never spoken values embedded in the subjects of our daily study. The study of law was made up mostly of empty pursuit of rules characterised by order, clarity, continuity but not by worth, utility or aspiration.

My first year of law study was met by modest academic success in face of minimal understanding but significant ability to regurgitate data. Second year simply frightened me by its torrential onslaughts of reading. There were seven final examinations at the end of second year, and two others midway through. In third year, I suddenly learned that what I was expected to know was neither complex nor subtle - learning law at my law school was easy, I just was not supposed to know that. I relaxed for the first time since registration and started to see some fascinating political, social, economic and philosophical issues. And while I could see many roles a teacher might play, the connection between myself and a career in law teaching had not been made by the time of my graduation. I was mostly concerned with graduating, trying out legal practice and leaving the dispassionate world of law study well behind me.

Like so many others before me and since I found that my legal 
education was an ambivalent and ambiguous preparation for a career as a lawyer. I was not at all prepared for the world of legal practice, as it happens, nor did I have any tools provided to me in law school to help me make the transition from law study to law practice. It was an ambiguous preparation because my colleagues and I knew that law practice was unimportant to law teachers, yet not so to us. Our careers would be in practice; why did they not care? It was ambivalent because so often my teachers would refer to practice, perhaps as a motivator to our efforts, as if it mattered to them, while we suspected that it really did not. Law is tested in action; why did that not matter?

I floundered for six months as a student-at-law before making connections between theory and practice, substantive rule and procedure, prescribed legal form and appropriate contents. The experience of practising law, or at least trying to practise law, provided a rich basis for learning about law in many of its aspects. I was for the first time personally confronted with the dismay, anguish and pain often felt by lawyers' clients, for whom the legal system is beyond understanding or being made understandable. I also came face to face, for the first time, with law's sense of purpose. It could be an instrument for the achievement of good, but more often than not I found it to be an instrument of delay, avoidance, protraction, frustration and oppression.

Over the course of my period under articles I eventually began to understand the ways and means of the legal process in action. My experience, at least, had led me to conclude that much fee earning legal work was not driven by the real issues in the case or the bona fide interests of lawyers and clients working to do justice under law according to the merits of the matter before them. In tune with this I had become quite adept at a specific kind of litigation practice. Both intellectually and emotionally I was involved in the making of arguments and in the pursuit of winning them. The more cases I had the harder I worked, the greater my "successes", the more I endeavoured to acquire the skills and knowledge necessary for what must be termed a shady kind of excellence. "Shady" because most of my cases were weak on the facts or law, or both, but I made progress for my clients on technical grounds, or by delaying tactics, or by methods calculated to diminish the other side's zeal or resources or both. In the short time during which I 
practised I am certain that I did not achieve the highest levels of ability. However, I am reasonably certain that I was at least competitive and often much better than average. The "thrill of victory" without much "agony of defeat" obscured what I was really doing, insofar as I was able to look at it, for quite a while. To some, even now, I did the "right" thing to deprive others of their lawful claims by "legal” argument.

Eventually, the cognitive dissonance caught up with me. At least I think that is what happened. I could no longer drag myself to work, to fight these causes and feel good about them, even when I was winning. Without repeating the gory details, suffice it to say that winning was no longer enough in face of the clear harm that was being done to individuals and the clear damage which was daily being inflicted upon an already over burdened legal system. Expertise and energy of all sorts were being put to no good purpose to further greedy gain or to avoid justified loss. My cognitive dissonance forced me to take action to protect myself.

I decided to apply to graduate law study late August during my first year of private practice. Following my articles I had completed Ontario’s Bar Admission Course and then entered into the litigation practice of my firm as a junior associate. Oddly enough, I found the much criticised Bar Admission Course useful to me and even stimulating. Despite its dull and routine teaching methods and its narrow focus on the trivia of legal information and lawyers' practice, it provided me with an opportunity to reflect my experience against the general body of practical information available to me at the time. Finally, I could find reason in law or at least see its relevance to life's problems - often for the first time for me. I began to struggle at a variety of levels about the experience of learning and many facets of law - theoretical, substantive, procedural. In fact it was at the Bar Admission Course that I began to identify the reasoned bases of law. So, by the time I had completed that period of litigating, as I have already described, I was ready seriously to reflect upon the wide variety of issues that had been thrown up from the commencement of my law studies to the end of six months as a qualified litigator a year and one-half later.

I left practice inspired to pursue a career as a law teacher: the connection had been made. A graduate degree was my first step. I 
came to advanced study in law with a twofold mission: first, I was determined to equip myself in the necessary contents of study to enable me to seek to enlighten others about the nature, purpose, function and aspirations of our legal system. Secondly, I would learn about learning and teaching so as to be able to facilitate an experience in others that would avoid the disengagement that I had felt in law study and the lack of connection with either theory or reality that pervaded my sense of what legal education was about during my days at law school.

I have told this truncated story of my motivations for entering a career in law because these experiences and the views and attitudes which flow from them cannot but have influenced my experiences as a law teacher and my reflections upon those experiences. I have thought it only fair that you should know what motivated me to choose what I truly consider to be a brilliant career, and what motivates me now.

\section{REFLECTION ON EXPERIENCE}

The writing of this paper has been a difficult project. In fact, I have begun to write it many times. However, trying to set out my thoughts about a career in the academy in an organised and informative way turned out to be a greater challenge than I had ever appreciated it would be. Stan Hotop, Dean of the Law School at the University of Western Australia, who kindly invited me here, gave me the opportunity to write on virtually any topic of interest to me pertinent to the theme of this conference, "Legal Academia". In choosing to write about "A Brilliant Career: Life as a Law Teacher" I made a decision to do what I find now extremely difficult to accomplish.

Until recently, I could not explain with clarity why I seized upon the law teacher's career for discussion. I have wondered whether it came to me because of the dearth of information and writing about our sub-profession. We do need to know more empirically about law teachers' careers and little has been said which describes, analyses or evaluates law teaching. I thought perhaps this paper would stimulate some activity which would shed light on who we are, what our goals are, and the extent to which we achieve them. And also, my personal experiences as a law teacher have brought me to certain conclusions that I would value being 
tested by colleagues' questions. But now it is obvious that I chose to write about a career in law teaching because the decision to take up that career was, on reflection, a momentous one for me. Now, 19 years after I made the commitment to become a law teacher I have been given a chance to reflect upon that decision, and to reconsider that commitment.

While I am an eternal optimist, I regret that I have come to believe that a career in law teaching, although it offers tremendous prospects in many ways for a variety of reasons, turns out to be a less than satisfying one for so many of our colleagues. I wonder not about its worth but rather about its real prospects. I will say why and later I will suggest how we might proceed.

As I have considered the various forces which affect us as law teachers I have concluded that legal academia provides a far from nurturing environment for most of us, impeding achievement by us and our students in most if not all aspects of learning about law. In such an environment our discipline and profession are not given the best opportunities to reach their potential, leaving our clients, our students and their clients, the public, less well-served by us than they should be. As you will see I consider this to be a reversible condition, but I feel equally that certain influences underlying academic life in law require neutralisation or redirection. The main purpose, then, of my writing is to provide a beginning diagnosis of what impairs our ability to achieve our potential and to suggest strategies which might lead to an improved future. I hope others will take up the challenge to study our subprofession and its members in sociological, demographic and psycho-social ways.

Before proceeding further I should probably spend a few lines declaring my major interests as a law teacher and my biases, although I am reasonably sure that those which are not already obvious will become clear soon in any event! To me the traditional dichotomies of academic and practical are fundamentally meaningless and often outright destructive to every aspect of our work. Legal practice is not mundane, technical, routine and bland. Theorising about law, lawyering and law's politics is not irrelevant, impractical and boring. Such characterisations offered by academics in one case and practitioners in the other typify the lack of awareness the members of both Town and Gown respectively commonly reflect. Law's role in society is too important to be 
mistreated by such nonsensical polarisations. Law matters as much in practice as it does in theory, and vice versa. Indeed, as the discipline which represents our society's fundamental values and beliefs about relationships and governance, our theories must be practicable and our practices must seek to conform with our theories. If legal professionals underrate and undervalue the academy their future will be affected, as will ours; but, most importantly our students' clients will suffer, for our graduates will not have had the benefit of the rich, deep and diverse kinds of education necessary to prepare them to adapt to the challenges posed by the great flux in all aspects of human endeavour.

The future of a society is necessarily in the hands of its youngest members. Their wisdom is perforce a product of their environment and their opportunities to learn, among other things. If legal academia is not peopled by scholar-teachers driven by the need to ensure that justice is done under law, both in theory and practice, then our future lawyers and leaders will be less well able to assure our safety. Realistically law schools play a small part in the making of a just society — but their role is nonetheless palpable and significant. Legal academia must be a valued place and a place of values. If a career in law teaching is unlikely to be brilliant, who will chose it, who will keep it, who will improve it? If the door to the academy revolves rather than swings, it will never develop the critical mass of committed persons necessary to ensure its greatest potential. We must value our place; our place must be valued.

And so the decision that I took to write on this topic, taken quickly on an instant, has despite the consternation, anxiety and frustration I often felt provided me with that rare opportunity to reflect on some issues which arise out of my experiences.

\section{ANALYSING EXPERIENCE}

While in my roles as a law teacher, educational administrator and occasional writer, I have had many opportunities to view and review colleagues in their work I had not yet developed a clear perception about a law teacher's career. Indeed, I am not sure that I have as yet. However, I have confirmed, as you must already have concluded, that law teaching is anything but a monolithic profession. We are a varied bunch with rich and diverse backgrounds. We do not come to legal academia with a single 
view. And to protect ourselves, we become committed to a pluralism which often has no other central core than the radical relativism which is denoted by its fundamentalist quality. Nowhere is the cry of "live and let live" more enshrined than in the academy. And so you will not be surprised to hear that I believe that a greater degree of homogeneity of purpose would serve us better than our sometimes sycophantic modelling of idiosyncrasy: common commitment to a purpose is no bad thing to ensure the maintenance of direction, accountability, performance and dedication.

As I tried to amplify my thoughts upon the subject I found my thoughts to be scattered - snap shots, notations, artifacts often without any clear focus, definite structure or discernible shape. But worse than not having a useful framework to analyse experience, which was both to hand and rang true, were the paralysing effects which my own experiences in legal academia have had on clarifying my perceptions. Experience does not ipso facto teach. Indeed, for me the specific recollection of events blurred insight and collapsed perspective, depriving me of viewpoints which might add perception to vision. And so for some time I could not find a way to abstract myself from my own experience to comment on the law teacher's career objectively: faced with the time-honoured challenge of disentangling self and other I could not now, as artfully and artificially as I might usually, disentangle these elements. I knew, and know, that in separating myself from my experiences I have changed my own reality, perhaps even destroyed it. It is not that my experiences have disappeared into their analysis, but rather that my analysis transforms the experiences, sometimes to fit it. Also, I have sought to separate my ideas from my personal experiences because I know that we law teachers are an audience more accepting of dispassionate, analytical examination than of emotionally engaged subjective interpretation.

\section{A BRILLIANT CAREER}

In selecting the title: “A Brilliant Career: Life as A Law Teacher" I have consciously evoked the ironic and self-absorbed meaning of the Australian novel from the title of which I have obviously borrowed.

What might be a brilliant career? A teacher's brilliance is ultimately found in her students' thoughts not her own. The 
profoundly intelligent scholar discovers so that others may dig more deeply and travel farther than he has. Our brilliant insights are sparks to ignite others' quests for ever more dramatic intellectual pyrotechnics. A brilliant career thus described empowers our students to exceed us and thereby fulfil1 ourselves and our goals. A brilliant career searches for meaning to be shared, expanded and diversified. This is why I wanted to be a teacher.

It is with considerable personal regret that I have concluded that few would describe life as a law teacher as "brilliant" either in fact or prospect for most of us who undertake it. This gem of a career, for all of its facets, does not shine radiantly very often, and the true intellectual brilliance which is said to be at its centre escapes most of our grasps naturally - but not for want of serious efforts on our behalf to achieve it. Still, I believe that we might share in a brilliant career if we were willing to challenge some assumptions which underlie our behaviour and discard values which do not suit our role; this would free us to change how we behave, and in the process we would, I predict, become dramatically more productive. We would not need to change the world, but we would have to change our view of it - especially of that part of the world that we inhabit. I have sadly concluded that we legal academics and our colleagues elsewhere in the academy often consciously choose against brilliance or are at least wilfully blind to its potentiation.

Why does this elude us? Where do we go wrong?

\section{A SOLITARY OR A SOCIAL CAREER?}

Many of us come to academic life for a kind of retreat, to find peace and quiet in order to pursue self-directed, personally initiated projects. Thinking about the colleagues I have known in many parts of the world I have concluded that they are highly individualistic, often idiosyncratic or even eccentric. This is often their attraction. Many are loners, frequently non-social in their orientation. It is not that we academics are unfriendly, but rather that we prefer individual work. People who choose a life in the academy are people with ideas, whose common approach to them is silent reflection followed by occasional and sometimes even exuberant declaration. Relatively few among us engage in daily Socratic dialogues with our neighbours. A large number of our colleagues would on average prefer to spend their time reading, writing and 
analysing rather than debating, exchanging and testing, except within themselves. In contrast, what one finds, of course, is that academic institutions are complex social organisations filled with institutional and personal relationships. We law teachers find our days filled with meetings, classes, functions, private tutorials and a wide range of personally demanding, essentially social activity. Each event puts us in contact with numbers of students, academic colleagues, legal practitioners and members of the public. While we may prefer to be alone with our work and our thoughts, we are forced into a wide range of social interactions which deprive us of the time and space we need and want, especially in our early days, as we struggle to figure out how to do our jobs, how to be scholars and teachers.

The settings in which we work require us to enter into social relationships therefore which I believe many of us sought to avoid by turning to the mythological cloisters of academe. The academy is of course a community, as were the monasteries of the Middle Ages from which the western university was borne. But the modern university varies dramatically from its progenitor institutions. In the earlier institutions, while all obligations were for a common purpose, socially completed obligations were clearly separated from individual ones. The community had a common cause which was served serially by clearly separated times for group and social interaction on the one hand, and periods of individual reflection and work, on the other. To be sure there were many models, but in each a central mission coupled with individual responsibility to the collective focused action, thought, and in those places, prayer. Nowadays one's individual life at the academy is intermingled with uncontrollable communal participation: our modern social orders do not permit the ancient separations of persons and functions. Those who wish to find time to steal themselves to their work can do so only if armed with self-created discipline; the academy no longer institutionalises the form and shape of work in a manner which is secure and predictable, as had been the case in the early times. Nor do we any longer ask that each member subordinate herself to the aspirations of the community. Without each member of the academy contributing to the common cause our goals will not be reached.

In short, the academy is not what many of us think it will be. 
Disappointment and disorientation often follow from such failed expectations.

\section{AS NEW ARRIVALS ...}

Newcomers to legal academia are of course true novices. In many parts of the world they come fresh from school, having no experience as teachers, scholars or legal practitioners. In North America a law teacher will usually begin her career before the age of thirty with a period of practice usually in the United States of America and with graduate study more common than practice in Canada. Elsewhere in the Common Law world she may begin a life at the academy at the early age of twenty-two or twenty-three years. On arrival, then, the law teacher has had little practical experience and knows little about the theory and practice of learning and teaching. While as a student many perceptions will have developed about the arts and sciences of education, it is uncommon that a tertiary educator would have any real grounding in educational theory or know much about effective instructional practices. And so apart from the occasional seminar as student presenter, most of us arriving at the law school have never structured more than a few minutes of learning for others, let alone the few hundreds of hours that are required of us as soon as we begin; and regrettably, we are often even less prepared to assess student performance than to teach. Testing perforce separates us from our learners, and our want of technique often seals the detachment. It is hard to be both friend and judge and no one helps us sort out our responsibilities in supporting learning and assessing its achievement.

Novices are expected to teach, examine, write and become part of the local management system of the law school in an environment they are likely barely to comprehend from the lecturer's side of the lectern. Innocent, ignorant and filled with hope, most of us learn that we cannot perform as teachers as we expected we could. Although we were certain we would avoid the pitfalls of our own teachers, students often tell us otherwise. The classroom can be a scary and often paralysing place. More than one bright graduate has experienced the fate of Wicked Witch of West when a class's cold water was tossed over him. A sea of expectant faces, bright eyes and firmly set lips, must be confronted without knowledge of the art of teaching and often with little confidence in 
the subject of what is being taught. Like the cruellest of occupations, we treat our young badly and they often repay us in kind in their times. What newcomer would not be embittered by a process which deludes her into the belief that she can do what she has clearly never been prepared to do? And, to add insult to injury, in many institutions and in many law school national cultures until recently there were no means through which a person interested in improving their abilities as a teacher could do so in an systematic and organized way. Now, of course, regular events are scheduled by the Australasian Law Teaching Clinic, The Canadian Teaching Clinic and The American Association of Law Schools to assist legal educators in their jurisdiction to improve their teaching. However, as teaching is of secondary importance, overall, to a career in legal academia these events do not necessarily receive as much support or assistance as their research counterparts.

Nor are many of us scholars on arrival at the university. A few essays in law school or a graduate thesis are little evidence of either our penchant for or skill in careful research, analysis, synthesis and evaluation. What made us good students might make us good scholars, but it is not inevitable. Our research methods are often severely restricted by the limited training and experience garnered by us as students who wrote mostly $100 \%$ final examinations and found specialist sub-collections to support our graduate theses, if we did one. Typically we know nothing of non-book- based research methods. Social science and archival research are not part of most of our legal educations. At the academy we are told we must produce, even though many will have neither the slightest idea about what to do or how to do it. There are rarely any internal support systems to help us grow and develop as scholars. Trial and error, error and trial, this is the way we learn to find information, ruminate upon it and digest it for others. Is it any wonder that our productivity is often low relative to colleagues in other disciplines? Something can and should be done, and is being done some places, to support and encourage our scholastic development when we are new, and even when we are not. 


\section{TEACHING OR SCHOLARSHIP? TEACHING AND}

\section{SCHOLARSHIP}

The internal recognition and promotion systems for staff within law schools, and indeed universities generally, reward scholarship through writing first and scholarship through teaching second. I have tried to figure out why it is really that we prize scholarship with so much greater emphasis than we do teaching. There are many grounds for speculation. It has frequently been said that teaching is a cluster of ineffable, unlearnable talents which cannot be taught, unlike scholarly habits, which can. Many say good teaching cannot be measured - student ratings are a beauty contest, not an assessment of excellence and skill. Besides, student ratings do not take into account the scholar's intellectual acuity and substantive learning to any sufficient degree to assess scholastic contributions. Also, students cannot be judges of the mastery of content by their teachers; and for some reason peer assessment of teaching is very rare indeed. Still other critics, while admitting that good teaching can be spotted, ("I know it when I see it"), say it cannot be described and certainly cannot be evaluated in an objective, criterion-referenced way. In short, written scholarship is unlike scholarship for teaching which is in the eye of the beholder. I am sure others would proffer other reasons. I have concluded that the real reasons behind the subordination of teaching's value in the university is that teaching is viewed as a process, not a product. Process is soft study. It lacks the toughness of substantive contents and the well-defined products of research. As such process is fundamentally about how, in the minds of many, rather than about what or why. The academy is for the most part actively disinterested in how to do things and seriously engages itself only in determining what things are doing and why. Needless to say this is a simplification. We cannot judge teaching as a process alone. Also its products, the accomplishments of students, are real measures of its processes.

Teaching is of course the ancient form of scholarship. Before Gutenberg the teacher-scholar was forced to disseminate learning and exchange ideas for the most part orally. Socratic dialogues became models of the expression of scholarship recognising that learning's reality was based in others' testing out of ideas. The 
lecture, modelled more on the oral tradition of telling, also of course teaches, but less well than methods requiring the student to focus her own thoughts on the ideas being exchanged. Scholarly activity which is focused on our thoughts and ideas only is really about us and is by definition more concerned about the teacher's mastery than classical student-oriented teaching which is concerned about the student's achievements. This is another reason why we prefer scholarship through writing over scholarship through teaching. To the extent that we undervalue teaching we undervalue a form of scholarship predicated on learning, debate and the human development which lead ineluctably from it.

\section{THE POLITICS OF HIGHER EDUCATION}

Law schools, and tertiary institutions generally, are profoundly politically enmeshed places. They are trouble zones without signage: sometimes I wonder what caution could be sufficient! We are particularly naive on arrival, expecting our newfound coworkers to be super human intellects incapable of neither narrow-mindedness nor shortsightedness. This failed expectation produces more than a few surprises.

It is frequently said that staff members clash often over trifles because there is so little else to fight for or about in the academy. Resources are tight and usually beyond an individual staff member's control in almost every event. I have my own personal working theory about these things. It is a theory about great intellects with small minds who go to extreme lengths over matters of little real moment in the name of big principles to hide their real purpose (self interest), thus justifying argumentation in the name of the mission of higher learning. Once the gauntlet of principle has been thrown it is a coward who does not take up the honoured duel. Ordinary, everyday, run-of-the-mill reasons like personal preference, error or fickleness are rarely owned-up to. And, in truth, the real reasons for battling may be fear of exposure of our ignorance, under-confidence, or our unwillingness to take on a serious project involving a great deal of work. So, she or he who meets principle with a request that each person do their part to share the burden of the achievement of the goals of the institution may be scorned and expected to fight on the higher ground of mock principle or risk loss of social acceptance. Thus are great minds 
blinded, sides taken and long term enmities initiated. In this way the mountain of principle is turned into a daily mole-hill of trumped-up importance. And, to make the situation worse, things that really should be done, issues that really should be debated are put to one side, often forever.

It is of course commonplace for there to be colleagues in the academy who have not communicated for years due to some such treacherous transactions: the real reason for the argument in the first place, often as not, was not only trivial but also base territoriality masquerading under some claim of principle or other. In legal academia territory is expressed in terms of control over subject matters taught (a kind of prescriptive right which attaches after a few years), membership on certain key committees (promotion, tenure, recruitment), nominations to the boards of centres, institutes and the like. Frequently in the politics of academic power-getting and giving and using there is even a territoriality of ideas! Yes, at the academy, our lighthouse beacon signals open-mindedness and a centre of free exchange, while within we sit in darkened spaces punishing the non-conforming, while empowering those who join together in repressive common causes. At once, the place of individual rights and beliefs is converted for mean purpose to a place of sudden community. It is not only lonely to be a humanist, or feminist, or socialist 'in some such places, it also downright dangerous to one's soul and psychological integrity.

Closely allied to the doctrine of territoriality is the ultimate claim, “academic freedom”. The doctrine of territoriality which I have already described carries with it the incidents of the right to control the contents, methods and sometimes even the identity of instructors on the course. Thus what is taught not only cannot, but should not be changed unless and until the colleague in charge makes the changes. This notion of subject-matter territoriality is intimately tied to the now elegantly extended principle that each member of staff is entitled to her own academic freedom. Now no one doubts that a person should be protected in his controversial opinions from the sanctions of those who are affected by their views, but the freedom has been extended beyond the privilege of comment to controlling the contents and teaching methods of a subject or course of study. Academic freedom, has been used to 
justify racist and sexist language and other instructional behaviours, to promote the right not to teach an agreed component of a syllabus, to refuse to adopt varied teaching and assessing methods, to preclude the evaluation of a course or a particular instructor's delivery of it, etc.

Even as these words are being uttered I can hear great gasping, loss of breath and the beginning of a deafening tumult which would, were it able, preclude my speaking freely now. Indeed, I mean no disrespect to the principle of freedom of speech for academic purposes: I merely do not think it should itself be used to preclude inquiry, debate and community-based decision-making. No one should be forced to say something against her will, either, of course. The interest of academic freedom is to provide opportunity for free comment and exchange without risk of sanction or discipline; it does not substitute for curriculum development, instructional design or of the assessment of learning. When such a freedom is not actually imperiled it is undermined and debased to claim that it is. In short this high-minded ideal protects low thoughts and petty-mindedness. Those who fear that the learning of new things will bring about change prevent that change in the name of academic freedom. Just as the Statute of Frauds, invented to prevent or punish deception often permitted it, so far too has the extension of the academic freedom maintained mediocrity and impeded development, while rarely in actual fact supporting truly provocative and penetratingly analytical speech.

\section{A DEDICATION TO CHANGE: A MISSION}

I believe in the university. In many ways it is the source of our greatest hope for the future. It is a place of inestimable potential. Its failures are of course ours, just as its successes are ours. While it may be difficult to state in a word the purpose of the university, its many objectives can be reduced to a couple of simply-stated goals. Among these goals surely are the preservation of what is of value and the creation and establishment of such change through learning as will benefit humankind. These aims might be achieved in diverse ways through various forms of scholarly activity, including research, writing and teaching. For many, it appears, these goals conflict in an ultimately disabling way, preventing or stifling change, interfering with innovation and creativity, blocking 
progress, thereby impeding the improvement in the quality of life's attributes and living itself. It is not easy to decide what to keep, what to reject and what to change. In the quest for change we might destroy that which should be preserved. Our conservationist and hence conservative instincts tend to overpower us. We refuse change, often without examination. We react, not think, and when we do we often prevent proaction which might produce an improved situation. We need more balance. The university must not fear its own central mission: to go where no-one else has gone before.

Preservation and innovation can and must of course coexist. How they are to be balanced is a function of a number of factors: needs, the capacity to change, the ability to deal with the consequences of change, the know-how to devise and implement change, the resources to support change, maintain it and improve its results, and so on. We should be sure to preserve what is valuable and ensure that it teaches its timeless lessons from the vantage points of different eras. A person should not be surprised that scholars and teachers resist change; nor should we be shocked to see whole organisations, institutions, behave fitfully in its face. In law, we understand better than most disciplines the conservative urge which is represented in judicial caution and the power of precedent decisions. Those who arrive among us filled with enthusiasm for growth, development, innovation and creation soon discover that the university may not be a welcoming environment. Interests vest quickly, change is hard, the organism is fragile or immune or massive, and so is resistant to innovation. It is hard to come with bright eyes and great expectations to a place of challenge, inquiry, debate and critique and find that the pages of our diaries or folios of our scholarship may be the only places accepting of our views. The university may then be a place not of freedom but rather of captivity. And still where else can one do what is done there? We make ourselves captive to the hope of the university even though we often cannot pursue our goals. Thinking that we can or should achieve our aspirations, we are held in place by manacles of our own making.

Of course, some institutions welcome provocative and innovative challenges. In their search for fresh views such places often forget that there must be a careful weighing of diversity and 
homogeneity in the views of a groups' members: a mission, if formed can be diluted by heterogeneity; a mission can equally be transfixed and immobilised by narrowness and single-mindedness of prospect. But the absence of a mission in or vision for one's institution is fundamentally debilitating and snuffs out the lights of new thinking before they are ever fully lit. Typically, the law school and the university are places of radical relativism - of live and let live, but on the express terms that the ship of knowledge not be swayed too much.

An institution without a purpose, like a person without a goal, eventually becomes hopeless - a place without hopes. "Excellence in scholarship and teaching” is not a statement of purpose, nor a statement of criteria for the assessment of achievement either. It is a beginning. Excellence for what? To what end? For whom? At what cost? In what context? By what measures? Missionless institutions make community virtually impossible. Community is the sense of joint purpose, mutual understanding and tolerance, and the commitment of one's energy and resources to the agreed purpose. Without community there is indecision or chaos or anarchy or worst, nothing at all. "In a world where everything is possible nothing is possible": it is true. We can work together or separately, but surely we must work towards something to which we ascribe, in which we believe and to which we can each contribute. Often this seems impossible or at least improbable in our institutions. Meaning seeps out of our careers and energy is sapped from our commitment. We sag; the institution sags.

\section{LAW TEACHERS, UNIVERSITIES AND THE LEGAL}

\section{PROFESSION}

Tertiary educational institutions are at least ambivalent about law schools. There are many reasons for this doubt about us. Lawyers are occasionally useful to the academy, especially in internal administrative decision-making. A quick opinion from a lawyer might save horrific fees which would be charged by a city law firm. Many in the university think us lawyers argumentative, hostile, polarising, self-centred and anti-intellectual. Others, expecting us to be rule-bound, cannot understand why we argue interpretations and subtleties. We are labelled "loopholers" when 
we argue on our own account and are taken for granted otherwise: finding legal means for self-protection is judged invidious; protecting the institution through the same means is considered required. Lawyers seem to bring out the worst in many people; our mere existence and especially our actual presence, evokes disdain or worse, sometimes. It has been said that the tie that binds more people together than any other is "the hatred of lawyers". If I hear one more lawyer joke, I occasionally think, I'll ... More often than not, to avoid being compared with Hamlet's mother, I simply join in, or initiate the jabbing. Those who malign lawyers, are not always wrong. More often that not they exaggerate for their own pleasure. Sometimes you can beat them by joining them; but never protest too much!

The serious-minded in the humanities claim we have no theory. Indeed, the common law legal system is in some terms designedly theory-free. If a theory to be a theory must preexist in espoused form, for example, the line of cases which exemplify it, I suppose an argument might be made out. Ex post facto theorisation, that is theorising by induction has long been a respectable business. Besides there are many other approaches to legal thought. We know it is not true that we are without theory; we have many, and we are developing more each day. Some who doubt us will say that rules derived from judicial decisions are not theories, they are practices and rarely the implementation of a theory either. Scientists - social, natural or applied — argue we engage in mere speculation; we are neither quantitative nor qualitative in our analyses. To them we have no method. Between the views of the humanities and social sciences we have neither contents of worth nor methods of value. Indeed, law is a developing discipline. The organising of rules by classification and category and the clearing of inconsistencies is hardly a significant study and surely not a discipline, some might say. We have limited forms, so far, for describing our knowledge be it in, of or about law. Our epistemology is only beginning its development as we face squarely, in many ways for the first time, as lawyers (not philosophers, political scientists, economists or social theorists) the nature of what we know and need to know in law. In sum, there is real scepticism in the academy of our place within it; were it not for law's power, authority and elite its students surely would have been 
kept in specialist trade schools with opticians, accountants and chiropodists for even longer. To our colleagues outside the law we are neither practitioners nor academics; we verge upon meritlessness.

While the academic traditions and ways of the humanities provide the traditional basis for theoretical discussions about law, they depend on a smaller base of primary works overall as compared to law and have a tradition of teaching and scholarship that is more esoteric, aesthetic and sensitive than the law's classically more technical, abstracted and cool ways. The social sciences' studies, although both qualitative and quantitative, have tended to be occupied with the application of the scientific method to human endeavour — including individuals, organisations, governments and so on. Recently law has connected to the social sciences to begin to test out its presumptions and assumptions as hypotheses. The new discipline of law is a fresh synthesis of the humanist and empiricist traditions in the context of doctrinal development, among other law themes. So law is neither a humanities nor social sciences subject yet it will be close kin to both always.

It is not comfortable to be viewed as a member of a fringe discipline, especially when one has been raised to see oneself another way! If we are underrated, maligned, disrespected or simply unaccepted were are likely to return the favour. This rarely makes for a pleasant situation. A life in a family where one is an unaccepted sibling produces lifelong hurts and leaves scars. As we justify our place in the academy both on its and our terms concurrently, we move to a position of improved comfort. But we are not there yet!

Langdell and Blackstone seem to be have unwittingly conspired across their centuries and the sea which links their jurisdictions to produce a disciplinary bias against the development of a broad and deep intellectual tradition in the study of law. Blackstones great Commentaries magnificently digested the poorly organised law of the day into easily deliverable and thematically categorised portions, ready for their distribution to the average lawyer who had no skill or experience in digesting common law cases into a rational scheme of rules. Langdell aspired to make Blackstones of every lawyer; for him law’s life-blood was its cases carefully analysed 
and parsed into their constituent elements to be compared, contrasted and extrapolated by the careful reader. Langdell made explicit the scientisation of law, bringing it into line with the burgeoning science of the nineteenth century which was based, in so far as it was feasible to do, on empirical knowledge and rational thought. This view of law of course yielded technically sound, rulebound, practitioners of the newly mechanised, industrialised world from which law has yet to totally evolve. It is ironic that the first Professors of Law at Oxford and Harvard would have left such double-edged and indelible marks. They began the struggle for acceptance in the university which still eludes us often now.

We law teachers also find minimal acceptance among our practitioner counterparts, and troublesomely, often also among our students. To legal practitioners, legal education's progeny, we seem over-privileged, easy-living, unrigorous academics whose life work is inaptly disconnected from the reality of law's daily operations. We know little about clients and their needs and less about the implementation of legal rules. Worst, our theories of law do not link to the exigencies of commercial transactions or the righting of wrongs or the service of the disadvantaged. To barbarian practitioners our work is moot, speculative and beside the point. Students take their cues from the practising profession and guide their own aspirations, expectations and aims by the profession's sometimes disabling pragmatism.

Academics are rarely made judges outside North America nor are their views referred to as frequently as they might be by practitioners or judges as they try cases in the courts. One or two among us achieve respectability within the profession, but the road is long, winding and steep. As we see ourselves from the vantage point of the practising profession, the Tower is neither very tall nor very white; it often feels like the one at London, a windowless dungeon, and like the one at Pisa, ready to fall. Sadly for us and them, those in legal practice have minimal regard for those who made their practices possible and who support their efforts by producing an accessible, useful and frequently practical legal literature. In our time we law teachers have sought variously to satisfy our colleagues in practice, to disregard them, to join them, to cooperate with them, to undermine them - we have sought to get their attention, and while at last we are beginning to succeed, 
our appeal has not yet been won. To them we are lesser professionals, and we may always be so in their eyes. Students learn this lesson early and well, often discounting our words only to profit from them later.

\section{GOVERNMENTS UNDERSUPPORT US}

Government has played its part with a certain style as well. For reasons about which I will speculate but which seem in contradiction to government's own best interests, the funding of tertiary law study has been pathetically low and consistently so.

For funding purposes law is often treated like the humanities and social sciences despite material disaffinities in structural terms with either. We have huge needs in our libraries, not only for secondary materials but for the mass of primary materials found in expensive serials. Law books are more often than not continuations in the secondary materials range as well: current law, subject area services, law journals and reviews, digests and encyclopedia are also, to some extent or completely, ongoing funding commitments. Legal search requires access to a wide range of multinational materials of this kind. And law databases, either remote or CDROM-based, also require maintenance and upkeep as continuations.

The rigorous education and development of cognitive abilities required of lawyers is not the product of lectures and unguided assignments. A lawyer's education requires variety, structure and direction. Law is not only an abstraction, it is a living organism within the body of society which must be understood in fact, in theory and in context. And as law plays such a important role in assessing the basic structures of western life it is a wonder that it can be treated with such disdain by those who depend upon its constructs for their very political existence. A cynic might speculate that governments do not want their actions tested against either rigorously justified theory or empirically sustainable facts. Or perhaps we take the status quo as a sufficient iteration of our potential for justice under law. Medicine of course receives special treatment: it is better resourced in all dimensions than law. This is not only because of the high cost of scientific equipment: needless to say, human health is a requisite for all action and must be adequately supported in its research and practice. However, our legal health and our social well-being depend on protecting the 
fundamental values which the law enshrines. This has become obvious where I live, Hong Kong. Foreseeing a different value system and legal tradition on the horizon for the territory with the return to China's sovereignty over Hong Kong, Hong Kong's government has now sought to reflect democratic values and liberal ideals (direct elections and a Bill of Rights) for the first time in its law to protect its people. Personal physical health is clearly of the highest importance and hence it is intimately tied to the wellbeing of our social system, enshrined and protected by law. Nor are we as well financed as science, engineering and various other disciplines including pharmacy, veterinary science and others.

The result of government underfunding of law study is that some of the best of our colleagues frequently seek careers of greater reward and recognition than legal academia can offer. Those who remain to teach and write feel exploited, underrated, and insecure. Real lawyers do law, they do not teach it. Underfunding discourages educational innovation, stifles research, ensures large classes, and precludes the use of advanced technologies in law teaching. No-one cares about the preparation of lawyers, it seems, except other lawyers, and their compasses rarely circumscribe a broad ranging circle of learning.

\section{INTERNAL UNREST: HISTORIC OPPORTUNITY}

Lately, like the pre-civil war union in America, we have become a house divided against itself. Riven by strife a new politics threatens our future. Equally, I believe, recent developments in legal education and scholarship may lead us to new learning which could transform both our discipline and our profession. First, let me say something about the strife, which I shall call the new intolerance. Then, I will try to demonstrate how this strife, seen positively, presents a pivotal opportunity in our pursuit of a better life in legal academia and of a brilliant career.

The new intolerance is, I suspect, the product of huge shifts in modern western society that were launched with the dawning of the industrial age and landed as the information age that has transformed all of our lives. Economic and political stability seem inextricably linked. We have become wealthier and less liable to civil disruption.

Law schools have become sites of tremendous upheaval. 
Radical feminist and critical theory of both the American and European strands have profoundly questioned existing legal structures reflected everywhere in every aspect of life. Unlike the law and economics movement which seemed to try ex post facto to justify analytical positivism, judicial conservatism and the free market ethos with economic theory, the critical movements (including feminism) have sought to undermine or expose the unsavoury values of our capitalist, malist and meritocratic ways. The critical tradition requires us to question systems, structures and their emanations and has asked us to declare our values and their implications. The critical approaches have sought to reflect content in process and process in content too.

The feminist and critical critiques, then, challenge the assumptions upon which our system is built and charge us to redefine them in value terms and to behave in all of our activities in a manner consistent with those newly-declared values. What has become so disconcerting to some is the silencing effect these views have had on much speech. For some time the feminist critique has claimed that traditional male dominated speech patterns, for example, and the structures which underlie them, have chilled the environment to women's expression. There is no doubt significant evidence of this. And, it cannot be doubted that it is reprehensible to reiterate and reinforce malist, racist, ageist and other forms of bias and bigotry. The feminist and critical analyses demonstrate that such bias is systemic, that is embedded in the deep structures and beliefs which support our forms of speech, for example. Malist, racist, ageist and other forms of discrimination, are perpetuated by the way in which many express themselves. Indeed, not only are our forms of expression justly under careful review but so are topics which expose discriminators' beliefs in a manner which tends to promote them, however, unwittingly. And so, cases of sexual assault against women and female children should not be used as examples of the development of rules, say in the law of evidence, unless the underlying problem of the abuse of women and children is also dealt with squarely and from a feminist perspective. The argument continues, so long as the problem is systemic it cannot be changed without modifying both the value system, the beliefs which underlie it and which are embedded and reflected in its structures, and the specific language used in the 
expression of thought. The result has tended to be seen as a silencing of some free expression in the name of positive, antidiscriminatory activity. This raises the ire of those who value free speech of all kinds as the highest order freedom and who see danger when free speech is threatened. We are obliged to demonstrate that such limitations are legitimate in context and support the responsible exchange of ideas.

In a paper of this kind justice cannot be done to the various points which would be made in a careful analysis of all of the arguments in this complex and subtle situation. However, it is obvious that current developments demonstrate a new zeal for fundamental analysis and critique - and most importantly a new commitment to justice as a legitimate study. In most cases this critique is followed by efforts at fresh syntheses of both old and new ideas. At worst, the total deconstructionist critical approach dispels the belief that there is any meaning other than what we individually take from a communication. But deconstructionism forces us to look at the many meanings which are possible in all communication. In the middle ground between rigid orthodoxy and flaccid liberalism is a range of justifiable .meanings. Debates of the kinds we are having now tend to extremes, while more elaborate complicated fusions nonetheless eventually arise from the sometimes seemingly irresolvably polarised debate. It is however certain that this radical review of law's values, politics and practices opens up the possibility of law's crossing new intellectual frontiers, yielding a genuine discipline of our own connected to doctrine but not narrowly circumscribed by the analytical process which produces only ratio decidendi. We have been forced beyond the educational goal sometimes expressed as teaching students to "think like an lawyer" which often has been the sole internally undefined raision d'etre of legal education, outside the acquisition of the substantial body of narrow legal doctrine. Now at last we can talk of justice and fairness without laughing embarrassedly.

What I have called the new intolerance which arises from the cluster of disciplinary focuses could, appropriately harnessed, take us beyond the narrow description of the discipline of law as the marriage of legal doctrine to technical rationality. To make room for these "new" thoughts we have been forced to ask those who have occupied so much space to date to remain quiet. This may be 
a small price, after all. In short, I believe that the prospects for a career in law teaching have risen substantially recently; we must seize the chance we have made for ourselves to describe a new scholarship and discipline.

\section{PROSPECTS ARE IMPROVING}

There are of course other trends which augur well for us. The concern for competence and even excellence in legal practice has been coupled with a drive to understand more fully the nature of our profession's obligations. Legal skills education is now receiving serious attention as we try to understand better what comprises the effective and efficient performance of legal work. Lawyer's work is being seen in the context of its effects in reality and lawyer's performances are being judged not just in their monetary results but by the propriety of the values they represent. This has brought our work closer to our colleagues in practice, bridging a divide which had been made inevitable by removing law students from law offices to law libraries and by making students' most important cases the ones in the books rather than those in the office. It has also placed us in a position to be critical or supportive of legal practice based on more than just surmise.

Perhaps most importantly, I believe we might have a brilliant career were we to seize upon the ever present opportunity to take scholarship through teaching seriously. Our students offer us each significant opportunities to find joy, pleasure and learning at the academy. Our students' motivations for law study are mixed most come to us to learn law because they wish to practice it in the service of justice; a few come for learning's sake. That should be no surprise. Most of us learn for personal and essentially practical purposes. A philosopher may learn in order to understand life's meaning better, to make its living easier, more fundamentally profitable. A biologist may learn in order to understand the living world around us so that we may serve it in a way that it may also serve us. Students' motivation is real and so long as we search out what is meaningful to them and treat that meaning as a bridge between us and them surely they will treat us more seriously and thus will support learning within the discipline.

The brilliance which a career in law teaching promises is within our grasp because it is within our making. Ironically, it is our 
reluctance to change, or more ironically, the need to change much quickly which too often blocks the achievement of our potential. Academic freedom must liberate not enslave, the learning/teaching process must be seen as developmental, as a link to our highest aspirations. A person's “merit” as a colleague must be measured by a diverse range of creditable contributions and not limited only to written expression. Each of our institutions and each of our colleagues must make a commitment to the achievement of specific described goals and we must be willing to play our part in pursuing their achievement, however diverse our ways of participating may be. The attitudes which we have developed which sometimes envelope us can and should be shifted upwardly. Each of us in each of our institutions must make a commitment to defining a locally relevant goal and stake out a part in achieving it. We must let go of the need to control others through our limits and permit energy to be expended on profit rather than loss. In short we need to see the role we play as facilitative, positive and future-oriented. We must continue to make arguments to our central administrations and to governments about our place of importance in academic and practical work. We need to show the legal profession that what we have to offer and claim a fair return in exchange. We must ensure that law teachers are rewarded sufficiently for their contribution and we must show the central value of that contribution in both theory and practice.

I have said we are poised to make a great success of our career if we take firmly in hand the rare opportunity which social and disciplinary developments now offer. The world has changed enough to make us believe that the discipline of law can also change positively. World political reorganisations and realignments, international trade, technological development and the general globalisation of debate about freedoms, rights and obligations all connect with law. Law will not only need to reflect the enormous shifts now occurring but provide mechanisms to forward them as they advance upon us. There will be no corner of human endeavour unrepresented by fundamental values ultimately expressed in the systems, structures and means created by or supported by law.

I believe we must integrate ourselves into our communities and build links with every element of our society. As teacher-scholars 
and the scholar-teachers we must practice what we teach and teach about the wide range of practice in the academy, the profession and the community. Legal academia must forge connections with government, volunteer organisations, private practice, business and demonstrate its real worth.

I chose a career in law teaching and continue that choice now because I firmly believe that in undertaking it I play a part in promoting the achievement of society's most important goals. Through teaching I participate in preparing for our future by building capable, thoughtful and sensitive graduates. In fostering an orientation to the future which is conscious of change and the accommodations which must accompany it I can contribute to both learnedness and learning. As a teacher I can create infinite opportunities for my students to contribute more than I have. A career in law teaching makes possible the active struggle for goodness, fairness and justice in our daily lives. The prospects for a brilliant career are bright. I believe it. We must believe it. We must act upon it. Nothing should be allowed to get in the way, especially not ourselves.

* Professor and Head, Professional Legal Education, Dean Faculty of Humanities and Social Sciences, City Polytechnic of Hong Kong, Faculty of Law, University of Windsor (on leave). This paper was delivered at "Legal Academia”, the Annual Meeting of the Australasian Law Teachers' Association, Law School, University of Western Australia, Perth, Western Australia, July 11$14,1991$.

(c) 1992. (1992) 3 Legal Educ Review 95. 